\title{
16. CALCAREOUS NANNOFOSSILS: LEGS 51 AND 52 OF THE DEEP SEA DRILLING PROJECT
}

\author{
William G. Siesser, Department of Geology, University of Cape Town, Rondebosch, South Africa
}

\section{INTRODUCTION}

Sites 417 and 418 are near the southern end of the Bermuda Rise (Figure 1). Several holes were drilled at these sites during DSDP Legs 51 and $52 .{ }^{1}$ The purpose of this report is (1) to record the distribution of calcareous nannofossils present, together with their relative abundance and preservation, and (2) to date samples from cores obtained at these two sites.

Table 1 lists species epithets of the calcareous nannofossils mentioned in this report.

\section{SITE 417}

\section{$\left(25^{\circ} 06.69^{\prime} \mathrm{N}, 68^{\circ} 02.82^{\prime} \mathrm{W}, 5480 \mathrm{~m}\right.$ water depth)}

Five holes were drilled at this site (Holes 417 to $417 \mathrm{D}$ ), recovering single mudline cores at Holes 417 and 417B, and no cores from the aborted drilling attempt at $417 \mathrm{C}$. Hole 417A was cored continuously to 417 meters sub-bottom. The sedimentary sequence is 211 meters thick here, but only the uppermost unit contains nannofossils (Quaternary; described by Gartner, this volume).

Hole $417 \mathrm{~B}$ is about 30 meters west of Hole 417A. A single core of nannofossil-bearing clay and nannofossil marl was obtained here. This core contains rare, poorly preserved Quaternary nannofossils in Section 417B-2-4 and Sample 417B-2, CC. The following species occur: Ceratolithus cristatus, Cyclococcolithus leptoporus, C. macintyrei, Gephyrocapsa oceanica, Gephyrocapsa spp., Helicosphaera carteri, and Rhabdosphaera claviger.

Hole $417 \mathrm{D}$ is about 450 meters west of Hole $417 \mathrm{~A}$. This hole was drilled to a sub-bottom depth of 708.5 meters, penetrating 344 meters of sediment before reaching basalt in Core 22. Coring was intermittent to a depth of 200 meters, then continuous to basement. The sedimentary sequence at 417D is divided into nine lithologic units (see Site Report, this volume). In general, a thin nannofossil clay at the top grades downward into a zone of brown pelagic and zeolitic clays. These overlie brown radiolarian ooze, clay, and sand, interbedded with multicolored zeolitic clay and green to black organic-rich claystones and chalks. The lowermost sedimentary unit, immediately overlying basalt, is an olive-gray nannofossil chalk.

These sediments contain few calcareous nannofossils, principally because of the great depth of this site during the later Cretaceous and Cenozoic. Only in Cores 1, 17, 19, 20, and 21 of Hole 417D were nannofossils found in sufficient numbers to justify study (Table 2). Section 417D-1-1 contains rare, poorly preserved specimens of Gephyrocapsa spp. and Ceratolithus cristatus. Section 417D-1-2 is barren,

\footnotetext{
'Drilling at these two sites was a joint effort involving the scientific staffs of Legs 51, 52, and 53; the author participated on Leg 52 only.
}

but Sections 417D-1-3 and 417D-1-4 contain an abundant, poorly to moderately preserved assemblage composed of the following species: Ceratolithus cristatus, C. telesmus, Coccolithus pelagicus, Cyclococcolithus leptoporus, C. macintyrei, Gephyrocapsa oceanica, Gephyrocapsa spp., Helicosphaera carteri, $H$. sellii, Pseudoemiliania lacunosa, Rhabdothorax cf. R. gerenus, Scyphosphaera globulosa, S. pulcherrima, Thoracosphaera heimi, T. saxea, and Umbilicosphaera sibogae.

Most specimens of Gephyrocapsa are small and lack crossbars; other very rare specimens appear to have crossbars, and I assign these to G. oceanica. The absence of crossbars may be due to dissolution, although early Pleistocene gephyrocapsids often have open centers in any case. Some authors would probably assign these to $G$. doronicoides, because of their lack of crossbars, although Gartner (1977) points out that they should not be assigned to the genus Gephyrocapsa for that very reason; i.e., they lack crossbars. Several species of Gephyrocapsa may occur in this core, but taxonomic resolution is very difficult with the light microscope. I have accordingly lumped them into only one category: Gephyrocapsa spp. I assign this core to the early Pleistocene because it contains $C$. macintyrei and Helicosphaera sellii, and Pseudoemiliania lacunosa.

Cores 2 through 15 in Hole 417D are barren or contain very rare, poorly preserved specimens. One specimen in Core 417D-5 resembles Cyclicargolithus floridanus (which has a middle Eocene to middle Miocene age range) but the identification is not definite. Cores 8 through 15 in Hole 417D contain rare specimens of Watznaueria barnesae. This long-ranging (Jurassic-Maestrichtian) form is robust and highly resistant to solution. I assign Cores 8 through 15 of Hole 417D to the Late Cretaceous on the basis of their stratigraphic position above Core 417D-17 (late Albian to late Cenomanian). Core 417D-16 is also probably Late Cretaceous; it contains a few poorly preserved specimens of Cretarhabdus cf. C. crenulatus, Parhabdolithus asper, and Watznaueria barnesae.

Core 417D-17 contains common to abundant, mostly moderately preserved nannofossils in Sections 1, 2, and 3. Species present include: Bidiscus rotatorius, Chiastozygus cuneatus, C. litterarius, Cretarhabdus conicus, $C$. aff. $C$. coronadventis, C. crenulatus, C. loriei, Cruciellipsis chiastia, Cylindralithus aff. C. serratus, Eiffellithus turriseiffeli, Hayesites cf. H. albiensis, Hayesites sp., Lithastrinus floralis, Lithraphidites carniolensis, Manivitella pemmatoidea, Parhabdolithus asper, P. embergeri, P. infinitus, $P$. splendens, Podorhabdus decorus, Prediscosphaera cretacea, $P$. cf. $P$. spinosa, Scapholithus fossilis, Stephanolithion laffittei, Tranolithus cf. T. orionatus, Vagalapilla elliptica, V. imbricata, Watznaueria barnesae, Zygodiscus diplogrammus, and Z. elegans. This assemblage suggests an age of late Albian to late Cenomanian. If the 


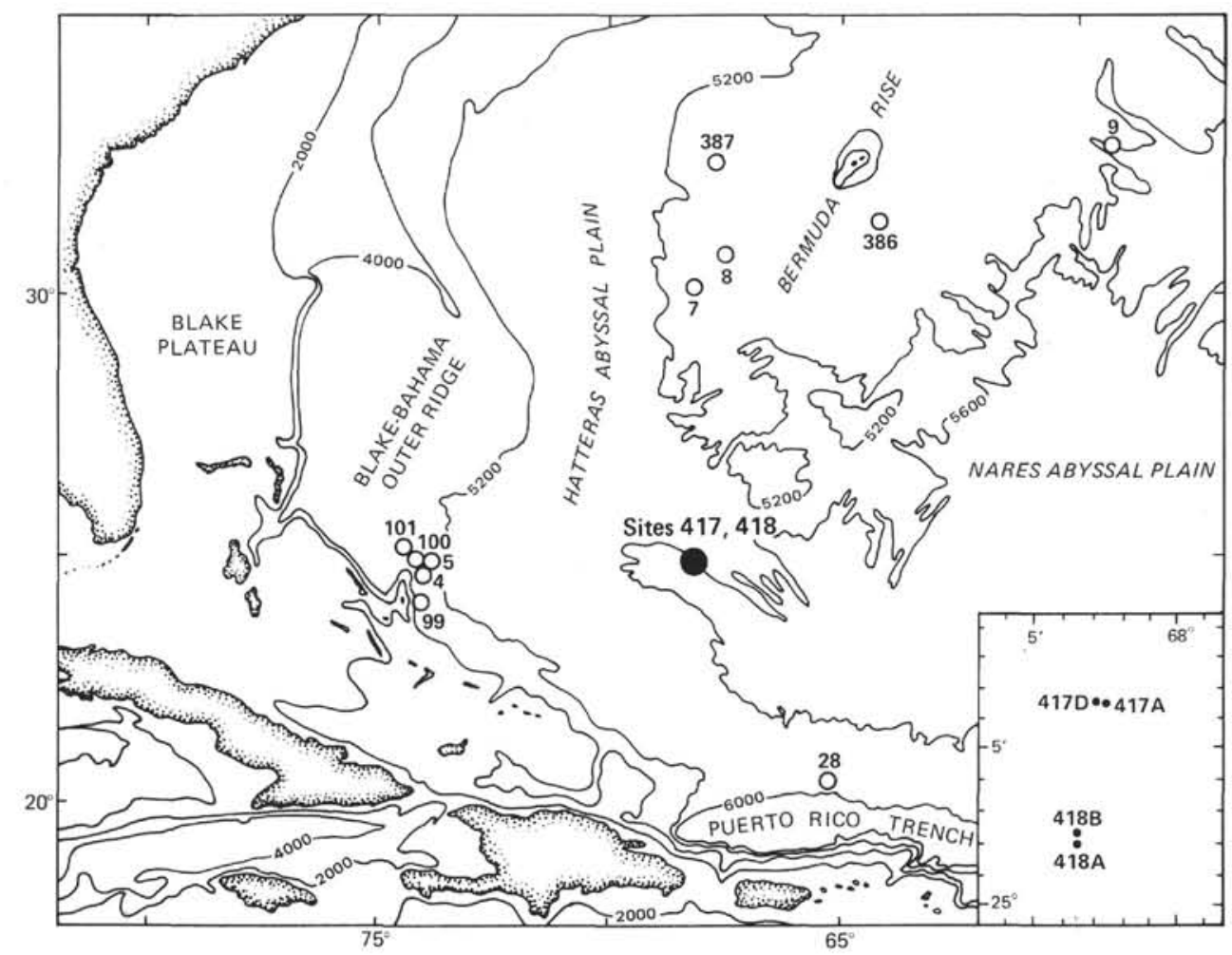

Figure 1. Location of Sites 417 and 418, DSDP/IPOD Legs 51 and 52.

identification of Hayesites albiensis is correct, this core can be assigned to the late Albian.

Sections 4 and CC of Cores 417D-17 and 417D-18 are barren or contain very rare specimens; the age is indeterminate.

Cores 417D-19 to Section 417D-21-3 contain rare to abundant nannofossils. Preservation is poor in all Core 417D-19 samples, but is somewhat better in Core 417D-20 where fossils are also generally more common. Species in these cores include: Assipetra infracretacea, Bidiscus sp., Chiastozygus litterarius, Cretarhabdus crenulatus, Cruciellipsis chiasta, Cylindralithus aff. C. serratus, Lithastrinus floralis, Lithraphidites carniolensis, Manivitella pemmatoidea, Markalius circumradiatus, Parhabdolithus asper, P. embergeri, P. splendens, Podorhabdus decorus, Rucinolithus irregularis, Stephanolithion laffitti, Vagalapilla elliptica, V. imbricata, Watznaueria barnesae, $W$. communis, Zygodiscus diplogrammus, and Z. elegans. Some specimens resemble Vagalapilla matalosa in the light microscope, but SEM examination shows that the resemblance is caused by calcite overgrowths thickening the tips of the crossbars of $V$. imbricata. This assemblage indicates a late Aptian to early Albian age.

Core 417D-21 contains this same assemblage down to at least $14 \mathrm{~cm}$ below the top of Section 3. However, a sample taken at $130-131 \mathrm{~cm}$ in Section 3 contains a much different assemblage, which I also found in Section 4. The assemblage includes all the species noted from Core 417D19 to Sample 417D-21-3, 13-14 cm (with the exception of Lithastrinus floralis) plus the significant addition of
Braarudosphaera bigelowi, Corollithion acutum, C. ellipticum, Cretarhabdus aff. C. coronadventis, Hayesites sp., Micrantholithus obtusus, Nannoconus bucheri, $N$. cf. $N$. kamptneri, N. wassalli, Podorhabdus dietzmanni, Reinhardites fenestratus, Rhabdolithus cf. $R$. rectus, and Tranolithus gabalus.

Micrantholithus obtusus is fairly common in these samples. This species ranges up to the top of the lower Aptian (Thierstein, 1973, 1976). Nannoconus wassalli also occurs up to about the same level (Roth and Thierstein, 1972). The presence of Chiastozygus litterarius and the absence of Lithastrinus floralis suggest that this interval is restricted to the lower Aptian, and can be referred to the Chiastozygus litterarius Zone (Roth and Thierstein, 1972), which more or less coincides with the boundaries of the lower Aptian. The lower Aptian has an age range of 112 to 115 m.y. (van Hinte, 1976).

It is uncommon to find Corollithion ellipticum in this zone. Thierstein (1973) reported that this species " . . . occurs in the Oxfordian of Great Britain, in all other localities it is known from the Upper Aptian to the Maastrichtian."

Scrapings from limestone deposited on a basalt cobble in Sample 417D-22, CC contain rare, poorly preserved specimens of Watznaueria and Cretarhabdus. Cores 22, 29, and 48 of Hole 417D contain basalt with occasional layers of well-indurated limestone. These thin limestone layers have only rare, poorly preserved specimens of Watznaueria cf. W. barnesae.

Table 2 shows the age, zonation, abundance, preservation, and distribution of calcareous nannofossils at Site 417 . 
TABLE 1

Nannofossil Species Considered in This Report (alphabetical order of species epithets)

Corollithion acutum Thierstein in Roth and Thierstein, 1972

Hayesites albiensis Manivit, 1971

Parhabdolithus angustus (Stradner) Stradner, 1968

Parhabdolithus asper (Stradner) Manivit, 1971

Watznaueria barnesae (Black) Perch-Nielsen, 1968

Braarudosphaera bigelowi (Gran and Braarud) Deflandre, 1947

Nannoconus bucheri Brönnimann, 1955

Gephyrocapsa caribbeanica Boudreaux and Hay in Hay, Mohler, Roth, Schmidt, and Boudreaux, 1967

Lithraphidites carniolensis Deflandre, 1963

Helicosphaera carteri (Wallich) Kamptner, 1954

Cruciellipsis chiastia (Worsley) Thierstein in Roth and Thierstein, 1972

Markalius circumradiatus (Stover) Perch-Nielsen, 1968

Rhabdosphaera claviger (Murray and Blackman) Kamptner, 1944

Watznaueria communis Reinhardt, 1964

Cretarhabdus conicus Bramlette and Martini, 1964

Cretarhabdus coronadventis Reinhardt, 1966

Cretarhabdus crenulatus Bramlette and Martini, 1964 emend. Thierstein, 1971

Prediscosphaera cretacea (Arkhangelsky) Gartner, 1968

Ceratolithus cristatus Kamptner, 1954

Chiastozygus cuneatus (Lyul'eva) Cepek and Hay, 1969

Podorhabdus decorus (Deflandre) Thierstein in Roth and Thierstein, 1972

Podorhabdus dietzmanni (Reinhardt) Reinhardt, 1967

Zygodiscus diplogrammus Deflandre and Fert, 1954

Zygodiscus elegans Gartner, 1968 emend. Bukry, 1969

Vagalapilla elliptica (Gartner) Bukry, 1969

Corollithion ellipticum Bukry, 1969

Parhabdolithus embergeri (Nöel) Stradner, 1963

Reinhardites fenestratus (Worsley) Thierstein in Roth and Thierstein, 1972

Lithastrinus floralis Stradner, 1962

Cyclicargolithus floridanus (Roth and Hay) Bukry, 1971

Scapholithus fossilis Deflandre in Deflandre and Fert, 1954

Tranolithus gabalus Stover, 1966

Rhabdothorax gerenus Kamptner, 1967

Scyphosphaera globulosa Kamptner, 1955

Thoracosphaera heimi (Lohmann) Kamptner, 1941

Vagalapilla imbricata (Gartner) Bukry, 1969

Parhabdolithus infinitus (Worsley) Thierstein in Roth and Thierstein, 1972

Assipetra infracretacea (Thierstein) Roth, 1973

Rucinolithus irregularis Thierstein in Roth and Thierstein, 1972

Nannoconus kamptneri Brönnimann, 1955

Pseudoemiliania lacunosa (Kamptner) Gartner, 1969

Stephanolithion laffittei Nöel, 1957

Cyclococcolithus leptoporus (Murray and Blackman) Kamptner, 1954

Chiastozygus litterarius (Gorka) Manivit, 1971

Cretarhabdus loriei Gartner, 1968

Cyclococcolithus macintyrei Bukry and Bramlette, 1969

Vagalapilla matalosa (Stover) Thierstein, 1973

Micrantholithus obtusus Stradner, 1963

Gephyrocapsa oceanica Kamptner, 1943

Tranolithus orionatus (Reinhardt) Reinhardt, 1966

Coccolithus pelagicus (Wallich) Schiller, 1930

Manivitella pemmatoidea (Deflandre) Thierstein, 1971

Scyphosphaera pulcherrima Deflandre, 1942

Hayesites radiatus (Worsley) Thierstein, 1976

Rhabdolithus'rectus Deflandre, 1954

Bidiscus rotatorius Bukry, 1969

Thoracosphaera saxea Stradner, 1961

Helicosphaera sellii (Bukry and Bramlette) 1969

Cylindralithus serratus Bramlette and Martini, 1964

Umbilicosphaera sibogae (Weber-van Bosse) Gaarder, 1970

Prediscosphaera spinosa (Bramlette and Martini) Gartner, 1968

Parhabdolithus splendens (Deflandre) Nöel, 1969

Ceratolithus telesmus Norris, 1965

Eiffellithus turriseiffeli (Deflandre) Reinhardt, 1965

Nannoconus wassalli Brönnimann, 1955 
TABLE 2

Calcareous Nannofossils at Holes 417B and 417D

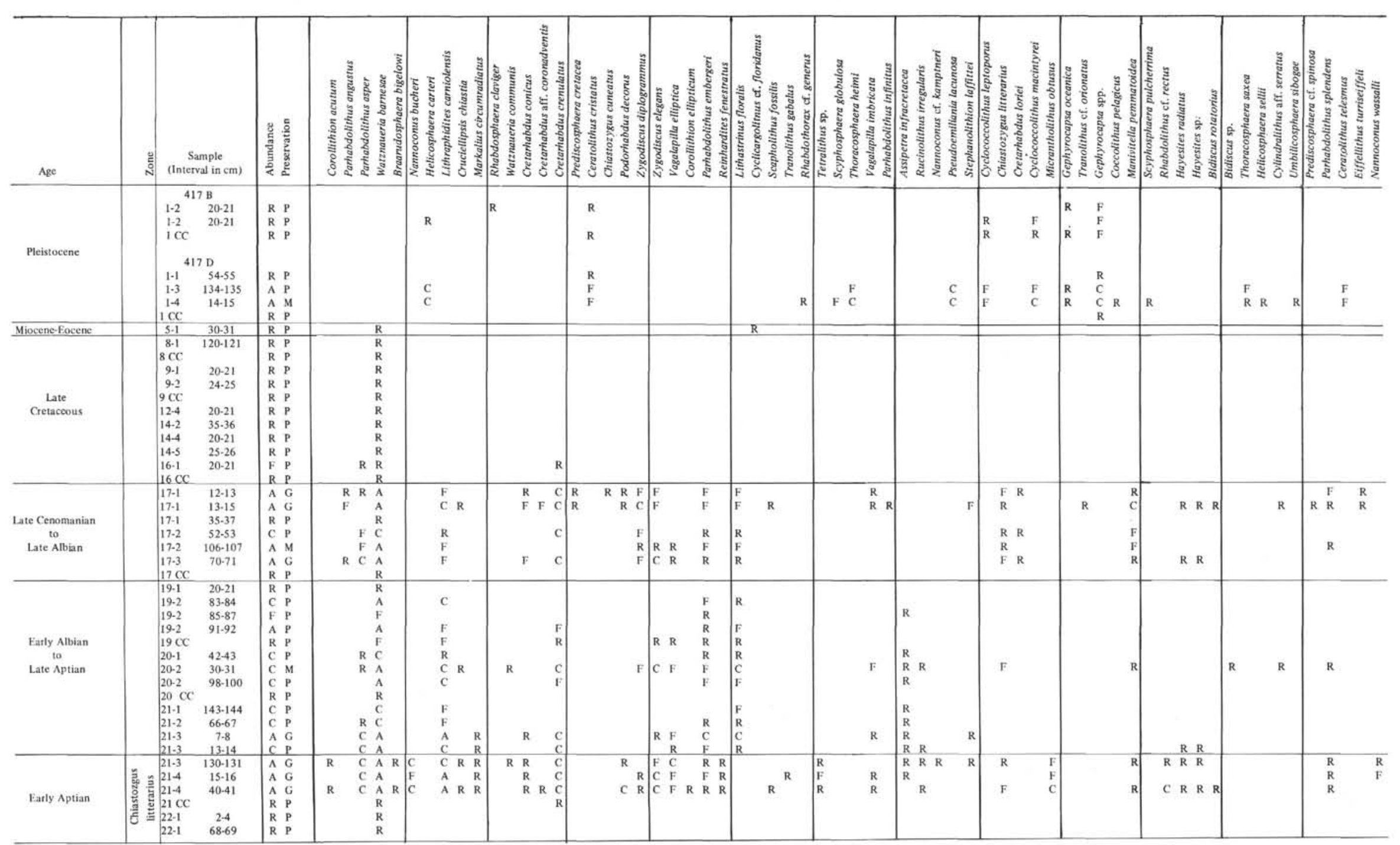

Note: Abundance; A - Abundant, C - Common, F - Few, R - Rare, Preservation; G - Good, M - Moderate, P - Poor 


\section{SITE 418}

\section{$\left(25^{\circ} 02.08^{\prime} \mathrm{N}, 6^{\circ} 03.45^{\prime} \mathrm{W}, 5511 \mathrm{~m}\right.$ water depth)}

Site 418 is located about $4.5 \mathrm{~km}$ SSW of Site 417 (Figure 1). We drilled three holes at this site. Holes 418 (a single mudline core) and $418 \mathrm{~A}$ are adjacent holes; Hole $418 \mathrm{~B}$ is about 130 meters north of the other two (I have not examined samples from Hole 418B).

The single core obtained at Hole 418 contains mostly pelagic clay. I found calcareous nannofossils only in Sections 3,4 , and CC. The fossils are poorly to moderately preserved and are abundant only in Section 4. The following species occur: Braarudosphaera bigelowi, Ceratolithus cristatus, C. telesmus, Cyclococcolithus macintyrei, $C$. leptoporus, Gephyrocapsa oceanica, Gephyrocapsa spp., Helicosphaera carteri, $H$. sellii, Pseudoemiliania lacunosa, Syracosphaera sp., Scyphosphaera pulcherrima, and Thoracosphaera saxea. Several reworked Neogene discoasters are present. As with Site 417, I assign this core to the early Pleistocene.

We drilled to a sub-bottom depth of 868 meters at Hole $418 \mathrm{~A}$. The sedimentary section penetrated is 324 meters thick. We began coring at 111 meters sub-bottom and cored continuously from there to basalt, with the exception of washed intervals of 19 meters between Cores 7 and 8, 28.5 meters between Cores 8 and 9, and 28.5 meters between Cores 9 and 10. Five lithologic units are present. They consist of brown pelagic clay with interbedded layers of nannofossil ooze at the top, grading downward into orange and brown zeolite and radiolarian pelagic clays. The lowermost units consist of blue-green and gray pelagic and nannofossil clays overlying brown, pink, gray, and green nannofossil ooze, clay, and chalk.

Cores 1 through 9 in Hole 418A are barren of calcareous nannofossils except for several poorly preserved specimens of Coccolithus pelagicus in Section 3-1 and Cyclicargolithus floridanus in Section 6-2.

Cores 10 to 11 in Hole 418 A contain rare to common, mostly poorly preserved calcareous nannofossils. Cores 12 , 13 , and 14 have an abundant, mostly moderately preserved assemblage. Species in Cores 10 through 14 include: $A s$ sipetra infracretacea, Braarudosphaera bigelowi, Chiastozygus litterarius, Cretarhabdus conicus, C. crenulatus, Cylindralithus aff. C. serratus, Lithastrinus floralis, Lithraphidites carniolensis, Manivitella pemmatoidea, Markalius circumradiatus, Parhabdolithus $\mathrm{cf}$. $P$. angustus, $P$. asper, Podorhabdus decorus, P. embergeri, P. splendens, Rucinolithus cf. $R$. irregularis, Stephanolithion laffittei, Vagalapilla elliptica, V. imbricata, Watznaueria barnesae, Zygodiscus diplogrammus, and Z. elegans. This assemblage suggests a late Aptian to early Albian age, at least for Cores 12,13 , and 14 of Hole $418 \AA$.

Core 418A-15 contains a well-bedded nannofossil chalk immediately overlying basalt. I found an abundant and moderate to well-preserved assemblage in the chalk. It contains all the species present in Cores 10 through 14 (with the exceptions of Lithastrinus floralis, Parhabdolithus cf. $P$. angustus, and Braarudosphaera bigelowi), and has, in addition: Bidiscus rotatorius, Watznaueria communis, Hayesites radiatus, Micrantholithus obtusus, Reinhardites fenestratus, Rhabdolithus $\mathrm{cf}$. $R$. rectus, and Tetralithus sp. The last five species are especially significant since they occur only in Core 21 which overlies basalt in Hole 417D. The notable exception is Nannoconus, which is common in Core 21 at Hole 417D but does not occur in Hole 418A. This distinctive assemblage is not found in any cores above 21 at 417D, nor above Core 15 at this site.

I thus tentatively date Core $418 \mathrm{~A}-15$ as early Aptian on the basis of its close similarity to the early Aptian assemblage in Core 417D-21. This interpretation is supported by the absence of Lithastrinus floralis, which first appears at the base of the late Aptian. However, it is difficult to explain the absence of Nannoconus and the rarity of Micrantholithus obtusus in sediments of the same age such as a short distance away from Hole 417D.

Table 3 shows the age, abundance, preservation, and distribution of calcareous nannofossils at Site 418 .

\section{ENVIRONMENTAL IMPLICATIONS}

The presence or absence of calcareous nannofossils in these samples is related to the position of Sites 417 and 418 with respect to the carbonate compensation depth (CCD) during Late Cretaceous and Cenozoic times, and probably to the restricted circulation of the early Atlantic Ocean during Early and Middle Cretaceous times.

Abundant, well-preserved nannofossils immediately above basement indicate a well-oxygenated site of accumulation above the CCD during the early Aptian. Micrantholithus, Nannoconus, and Braarudosphaera are all genera characteristic of nearshore waters. Nannoconids are known to prefer warm, calm, carbonate-rich waters. Rucinolithus irregularis and Hayesites radiatus also indicate tropical waters (Thierstein, 1976). This suggests that these sites were situated under warm waters fairly close to shore during the early Aptian.

Shortly after this time, intermittent layers of euxinic black claystones were deposited as the result of periodic stagnation of bottom waters, with attendant lowering of $p \mathrm{H}$ which dissolved calcium carbonate and prevented accumulation of calcareous biogenic sediments. These barren, euxinic layers were repeatedly followed by deposition of normal biogenic pelagic sediments. This episodic stagnation-oxygenation could be the result of periodic fluctuations in local oceanic circulation patterns, which would intermittently oxygenate otherwise stagnant basins of accumulation set in the rugged topography of the early Atlantic Ocean floor.

As the Atlantic continued to widen and deepen, these sites eventually subsided beneath the CCD and further calcareous sediments could not accumulate by normal processes. This probably happened during or just after the Cenomanian, as Core 417D-17 contains the last calcareous sediments prior to the Quaternary. This core also contains the last euxinic claystones, suggesting that the Atlantic had established a well-developed circulation pattern by Cenomanian times. Radiolarian and pelagic clays thus became the dominant sedimentary facies. Only in the Quaternary do we again find calcareous sediments. However, this thin calcareous zone probably represents rapid lateral transport (by slumping or a turbidity current) and burial of sediment derived from a topographically higher site of accumulation, as Sites 417 and 418 have certainly been below the CCD during all the Quaternary period. 
TABLE 3

Calcareous Nannofossils at Holes 418 and 418A

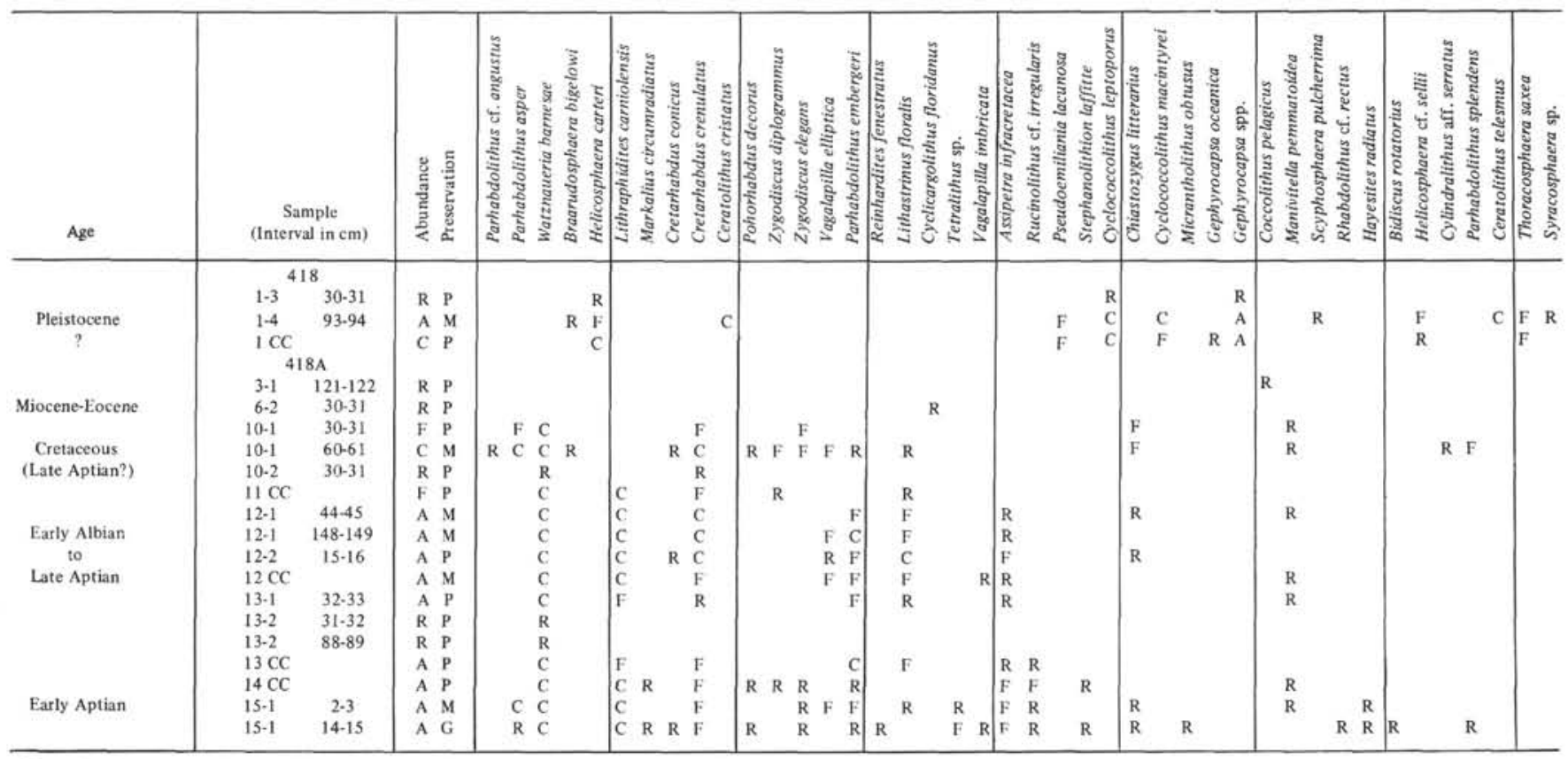

Note: Abundance; A - Abundant, C - Common, F - Few, R - Rare. Preservation; G - Good, M - Moderate, P - Poor.

\section{ACKNOWLEDGMENTS}

Dr. Franca Proto Decima and Dr. Stefan Gartner kindly examined the manuscript and plates, and I thank them for their helpful comments. I also thank the Electron Microscopy Unit at the University of Cape Town for the use of its facilities.

\section{REFERENCES}

Gartner, S., 1977. Calcareous nannofossil biostratigraphy and revised zonation of the Pleistocene, Marine Micropaleontology, v. 2, p. $1-25$.

Roth, P. H. and Thierstein, H., 1972. Calcareous nannoplankton: Leg 14 of the Deep Sea Drilling Project. In Hayes, D. E.,
Pimm, A. C., et al., Initial Reports of the Deep Sea Drilling Project, v. 14: Washington (U.S. Government Printing Office), p. 421-485.

Thierstein, H. R., 1973. Lower Cretaceous calcareous nannoplankton biostratigraphy, Abhandlungen der Geologischen Bundesanstalt, v. 29, p. 1-52.

, 1976. Mesozoic calcareous nannoplankton biostratigraphy of marine sediments, Marine Micropaleontology, v. 1, p. $325-362$.

van Hinte, J. E., 1976. A Cretaceous time scale, The American Assoc. Petrol. Geol. Bull., v. 60, p. 498-516. 



\section{PLATE 1 \\ Scanning Electron Micrographs}

Figure 1 Nannofossil assemblage, including Watznaueria barnesae, Zygodiscus elegans, Hayesites sp. and Stephanolithion laffittei. Samples 417D-171, $13-15 \mathrm{~cm}$. Bar scale: $6 \mu \mathrm{m}$.

Figure 2 Corollithion acutum, distal side. Sample 417D-21-4, 40-41 cm. Bar scale: $4 \mu \mathrm{m}$.

Figure 3

Corollithion acutum, proximal side. Sample 417D-21-3, 130-131 cm. Bar scale: $2 \mu \mathrm{m}$.

Figure 4 Parhabdolithus angustus, distal side. Sample 417D-17-1, 13-15 cm. Bar scale: $2 \mu \mathrm{m}$.

Figure 5

Parhabdolithus asper, proximal side. Sample 418A-15-1, $14-15 \mathrm{~cm}$. Bar scale: $4 \mu \mathrm{m}$.

Figure 6

Parhabdolithus asper, proximal side (lower left). Stephanolithion laffittei, proximal side (right center). Watznaueria barnesae, distal side (upper right). Sample 417D-21-4, 40-41 cm. Bar scale: $6 \mu \mathrm{m}$.

Figure 7

Watznaueria barnesae, distal side (coccosphere). Sample 417D-21-4, 40-41 cm. Bar scale: $6 \mu \mathrm{m}$.

Figure 8 Watznaueria barnesae, proximal side. Sample 417D-17-1, 13-15 cm. Bar scale: $2 \mu \mathrm{m}$.

Figure 9

Nannoconus bucheri. Sample 417D-21-3, 130-131 cm. Bar scale: 4 $\mu \mathrm{m}$.

Figure 10

Nannoconus sp. Sample 417D-21-3, 130-131 cm. Bar scale: $4 \mu \mathrm{m}$.

Figure 11

Nannoconus sp. Sample 417D-21-3, 130-131 cm. Bar scale: $4 \mu \mathrm{m}$.

Figure 12

Lithraphidites carniolensis, Sample 417D-17-1, 13-15 cm. Bar scale: 4 $\mu \mathrm{m}$.

Figure 13 Lithraphidites carniolensis, Sample 417D-17-1, 13-15 cm. Bar scale: 4 $\mu \mathrm{m}$.

Figure 14 Cruciellipsis chiastia, distal side. Sample 417D-17-1, 13-15 cm. Bar scale: $2 \mu \mathrm{m}$.

Figure 15 Cruciellipsis chiastia, proximal side. Sample 417D-21-4, 40-41 cm. Bar scale: $2 \mu \mathrm{m}$.

Figure 16 Cruciellipsis chiastia, distal side, and pyrite framboid. Sample 417D21-4, 40-41 cm. Bar scale: $4 \mu \mathrm{m}$.

Figure 17 Watznaueria communis, distal side. Sample 418A-15-1, 14-15 cm. Bar scale: $2 \mu \mathrm{m}$.

Figure 18 Watznaueria communis, proximal side. Sample 417D-21-3, 130-131 cm. Bar scale: $4 \mu \mathrm{m}$.

Figure 19 Cretarhabdus conicus, distal side. Sample 417D-21-3, 130-131 cm, Bar scale: $2 \mu \mathrm{m}$. 
PLATE 1
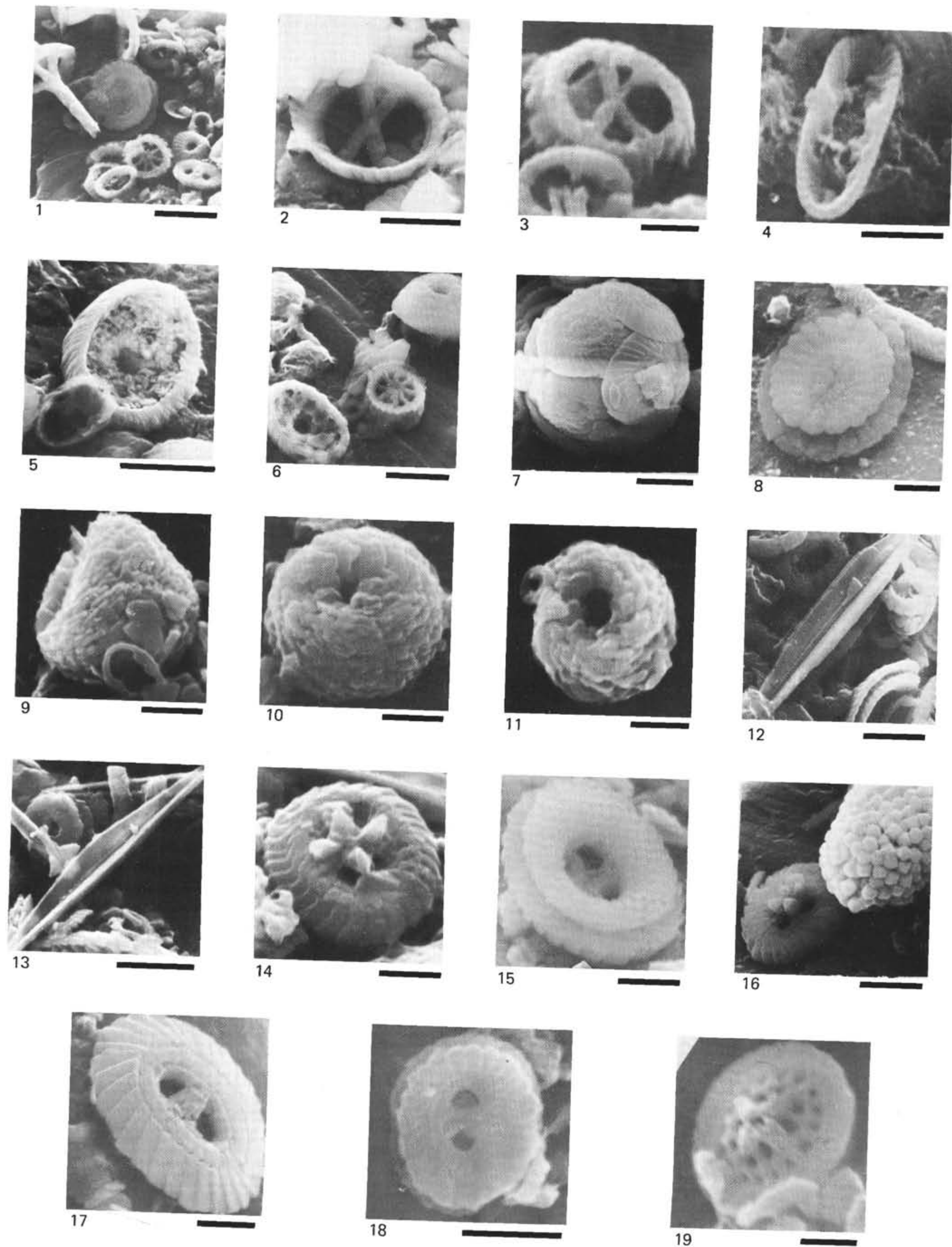
PLATE 2

Scanning Electron Micrographs

Figure 1 Cretarhabdus aff. C. coronadventis, distal side. Sample 417D-17-1, 13-15 $\mathrm{cm}$. Bar scale: $4 \mu \mathrm{m}$.

Figure 2 Cretarhabdus aff. C. coronadventis, distal side. Sample 417D-17-1, 13-15 cm. Bar scale: $2 \mu \mathrm{m}$.

Figure 3 Cretarhabdus crenulatus, distal side. Sample 417D-17-1, 13-15 cm. Bar scale: $4 \mu \mathrm{m}$.

Figure 4 Cretarhabdus crenulatus, proximal side. Sample 417D-17-1, 13-15 cm. Bar scale: $4 \mu \mathrm{m}$.

Figure 5

Cretarhabdus sp. Sample 417D-21-3, 130-131 cm. Bar scale: $4 \mu \mathrm{m}$.

Figure 6

Prediscosphaera cretacea. Sample 417D-17-1, 13-15 cm. Bar scale: 4 $\mu \mathrm{m}$.

Figure 7

Prediscosphaera cretacea. Sample 417D-17-1, 13-15 cm. Bar scale: 4 $\mu \mathrm{m}$.

Figure 8 Podorhabdus dietzmanni, distal side. Sample 417D-21-3, 130-131 cm. Bar scale: $4 \mu \mathrm{m}$.

Figure 9 Zygodiscus diplogrammus, distal side. Sample 417D-17-1, 13-15 cm. Bar scale: $4 \mu \mathrm{m}$.

Figure $10 \quad$ Zygodiscus diplogrammus, proximal side. Bar scale: $2 \mu \mathrm{m}$.

Figure 11 Zygodiscus elegans, distal side. Sample 417D-21-4, 40-41 cm. Bar scale: $2 \mu \mathrm{m}$.

Figure 12 Zygodiscus elegans, proximal side. Sample 417D-21-3, 130-131 cm. Bar scale: $4 \mu \mathrm{m}$.

Figure 13 Vagalapilla elliptica, distal side. Sample 417D-21-4, 40-41 cm. Bar scale: $2 \mu \mathrm{m}$.

Figure 14 Vagalapilla elliptica, proximal side. Sample 417D-21-4, 40-41 cm. Bar scale: $2 \mu \mathrm{m}$.

Figure 15 Corollithion ellipticum, proximal side. Sample 417D-21-4, $40-41 \mathrm{~cm}$. Bar scale: $1 \mu \mathrm{m}$.

Figure 16 Parhabdolithus sp., side view. Sample 417D-17-1, 13-15 cm. Bar scale: $4 \mu \mathrm{m}$.

Figure 17 Reinhardites fenestratus, distal side, and Bidiscus rotatorius, distal side. Sample 417D-21-4, 40-41 cm. Bar scale: $4 \mu \mathrm{m}$.

Figure 18 Lithastrinus floralis. Sample 417D-17-1, 13-15 cm. Bar scale: $2 \mu \mathrm{m}$.

Figure 19 Lithastrinus floralis. Sample 417D-17-1, 13-15 cm. Bar scale: $4 \mu \mathrm{m}$. 
PLATE 2
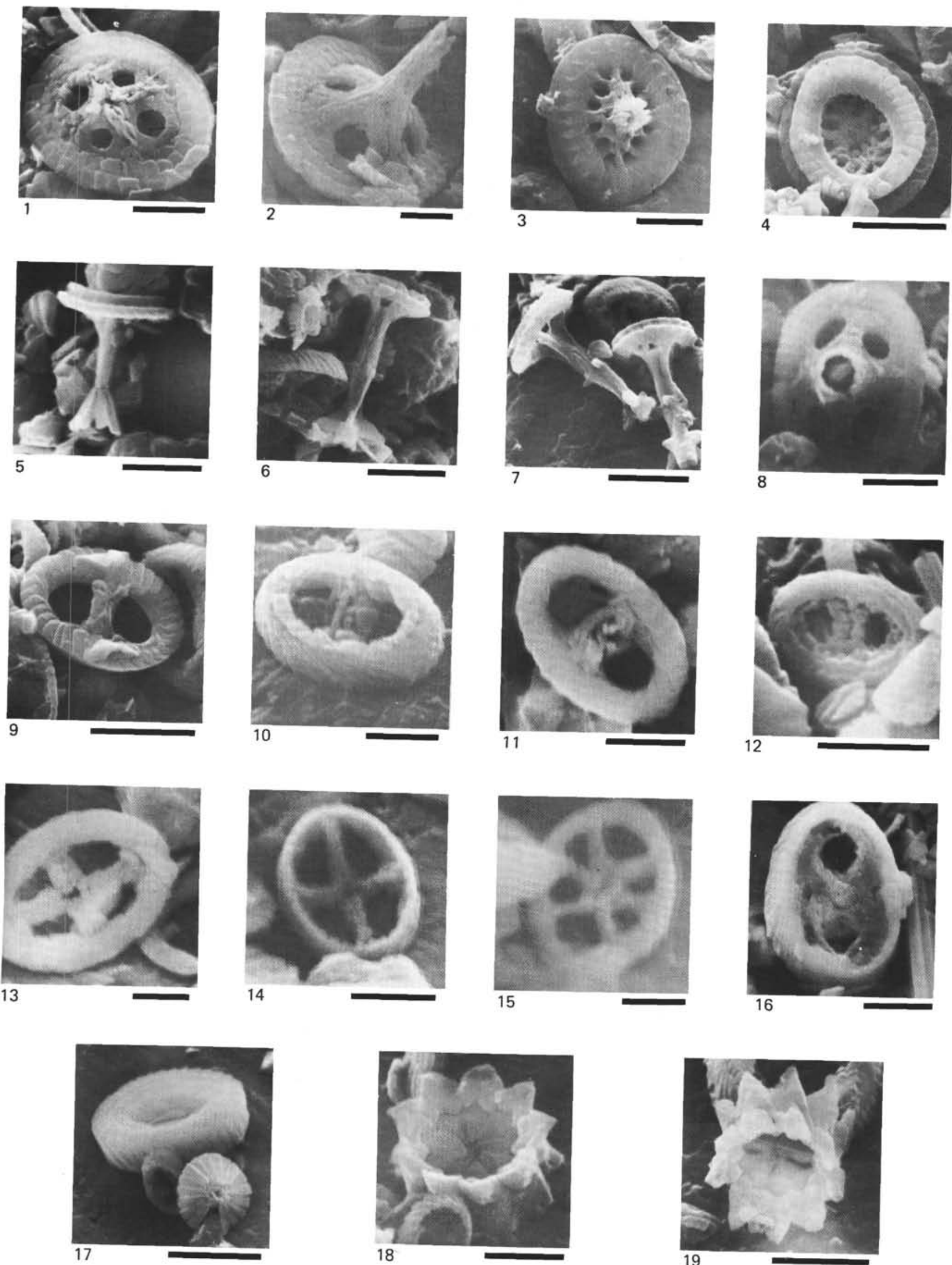
PLATE 3

Scanning Electron Micrographs

Figure 1

Figure 2

Figure 3

Figure 4

Figure 5

Figure 6

Figure 7

Figure 8

Figure 9

Figure 10

Figure 11

Figure 12

Figure 13

Figure 14

Figure 15

Figure 16

Figure 17

Figure 18

Figure 19
Scapholithus fossilis. Sample 417D-21-4, 40-41 cm. Bar scale: $2 \mu \mathrm{m}$.

Tranolithus gabalus, proximal side. Sample 417D-21-3, 130-131 cm. Bar scale: $2 \mu \mathrm{m}$.

Hayesites cf. H. albiensis. Sample 417D-17-1, 13-15 cm. Bar scale: 1 $\mu \mathrm{m}$.

Vagalapilla imbricata, distal side. Sample 418A-15-1, 14-15 cm. Bar scale: $2 \mu \mathrm{m}$.

Vagalapilla imbricata, proximal side (upper right) and Vagalapilla elliptica, distal side (lower left). Sample 418A-15-1, 14-15 cm. Bar scale: $4 \mu \mathrm{m}$.

Rucinolithus irregularis, distal side. Sample 417D-20-2, 30-31 cm. Bar scale: $2 \mu \mathrm{m}$.

Rucinolithus irregularis, proximal side. Sample 417D-21-3, 130-131 $\mathrm{cm}$. Bar scale: $2 \mu \mathrm{m}$.

Stephanolithion laffittei, distal side. Sample 417D-21-3, 130-131 cm. Bar scale: $2 \mu \mathrm{m}$.

Stephanolithion laffittei, proximal side. Sample 418A-15-1, $14-15 \mathrm{~cm}$. Bar scale: $2 \mu \mathrm{m}$.

Chiastozygus litterarius, distal side. Sample 417D-21-4, 40-41 cm. Bar scale: $4 \mu \mathrm{m}$.

Chiastozygus litterarius, distal side. Sample 417D-17-1, 13-15 cm. Bar scale: $2 \mu \mathrm{m}$.

Micrantholithus obtusus, segment. Sample 418A-15-1, 14-15 cm. Bar scale: $2 \mu \mathrm{m}$.

Manivitella pemmatoidea, distal side. Sample 417D-17-1, 13-15 cm. Bar scale: $4 \mu \mathrm{m}$.

Manivitella pemmatoidea, proximal side. Sample 417D-17-1, 13-15 $\mathrm{cm}$. Bar scale: $4 \mu \mathrm{m}$.

Rhabdolithus cf. $R$. rectus. Sample 417D-21-3, 130-131 cm. Bar scale: $4 \mu \mathrm{m}$.

Rhabdolithus cf. $R$. rectus and Lithraphidites carniolensis. Sample 417D-21-4, 40-41 cm. Bar scale: $6 \mu \mathrm{m}$.

Bidiscus rotatorius, distal side. Sample 417D-17-1, 13-15 cm. Bar scale: $4 \mu \mathrm{m}$.

Cylindralithus aff. C. serratus, side view. Sample 417D-17-1, 13-15 cm. Bar scale: $4 \mu \mathrm{m}$.

Parhabdolithus splendens, distal side. Sample 417D-17-1, 13-15 cm. Bar scale: $4 \mu \mathrm{m}$. 
PLATE 3
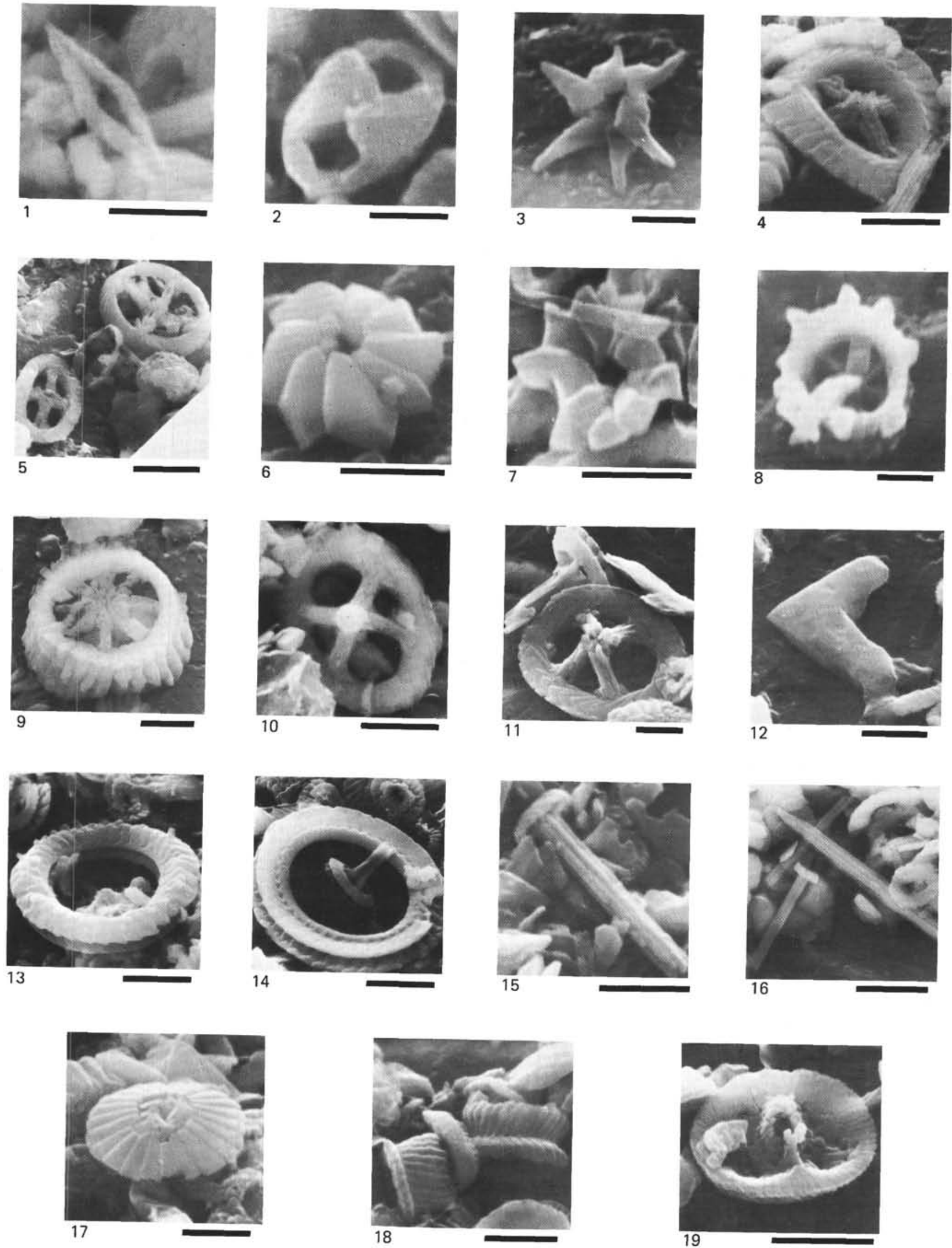
Scanning Electron Micrographs

Figure 1 Ceratolithus cristatus. Sample 417D-1-4, 14-15 cm. Bar scale: $4 \mu \mathrm{m}$.

Figure 2 Ceratolithus cristatus. Sample 417D-1-3, 134-135 cm. Bar scale: 6 $\mu \mathrm{m}$.

Figure 3 Ceratolithus cristatus. Sample 417D-1-4, 14-15 cm. Bar scale: $6 \mu \mathrm{m}$.

Figure 4 Gephyrocapsa sp., distal side. Sample 417D-1-4, 14-15 cm. Bar scale: $1 \mu \mathrm{m}$.

Figure 5 Gephyrocapsa sp., proximal side. Sample 417D-1-4, 14-15 cm. Bar scale: $1 \mu \mathrm{m}$.

Figure 6

Rhabdothorax gerenus. Sample 417D-1-4, 14-15 cm. Bar scale: $4 \mu \mathrm{m}$.

Figure 7

Scyphosphaera globulosa. Sample 417D-1-4, 14-15 cm. Bar scale: 6 $\mu \mathrm{m}$.

Figure 8 Scyphosphaeraglobulosa. Sample417D-1-4, 14-15cm. Barscale: $8 \mu \mathrm{m}$.

Figure 9 Thoracosphaera heimi. Sample 417D-1-4, 14-15 cm. Bar scale: $10 \mu \mathrm{m}$.

Figure 10 Pseudoemiliania lacunosa, distal side. Sample 417D-1-4, 14-15 cm. Bar scale: $2 \mu \mathrm{m}$.

Figure $11 \quad$ Pseudoemiliania lacunosa, proximal side. Sample 417D-1-4, 14-15 cm. Bar scale: $2 \mu \mathrm{m}$.

Figure 12 Cyclococcolithus leptoporus, distal side (lower right) and Cyclococcolithus macintyrei, distal side (upper left). Sample 417D-1-4, 14-15 cm. Bar scale: $6 \mu \mathrm{m}$.

Figure 13 Cyclococcolithus macintyrei, distal side. Sample 417D-1-4, 14-15 cm. Bar scale: $4 \mu \mathrm{m}$.

Figure 14 Cyclococcolithus macintyrei, proximal side. Sample 417D-1-4, 14-15 cm. Bar scale: $4 \mu \mathrm{m}$.

Figure 15 Thoracosphaera saxea. Sample 417D-1-4, 14-15 cm. Bar scale: $2 \mu \mathrm{m}$.

Figure 16 Umbilicosphaera sibogae. Distal side. Sample 417D-1-4, 14-15 cm. Bar scale: $4 \mu \mathrm{m}$. 
PLATE 4
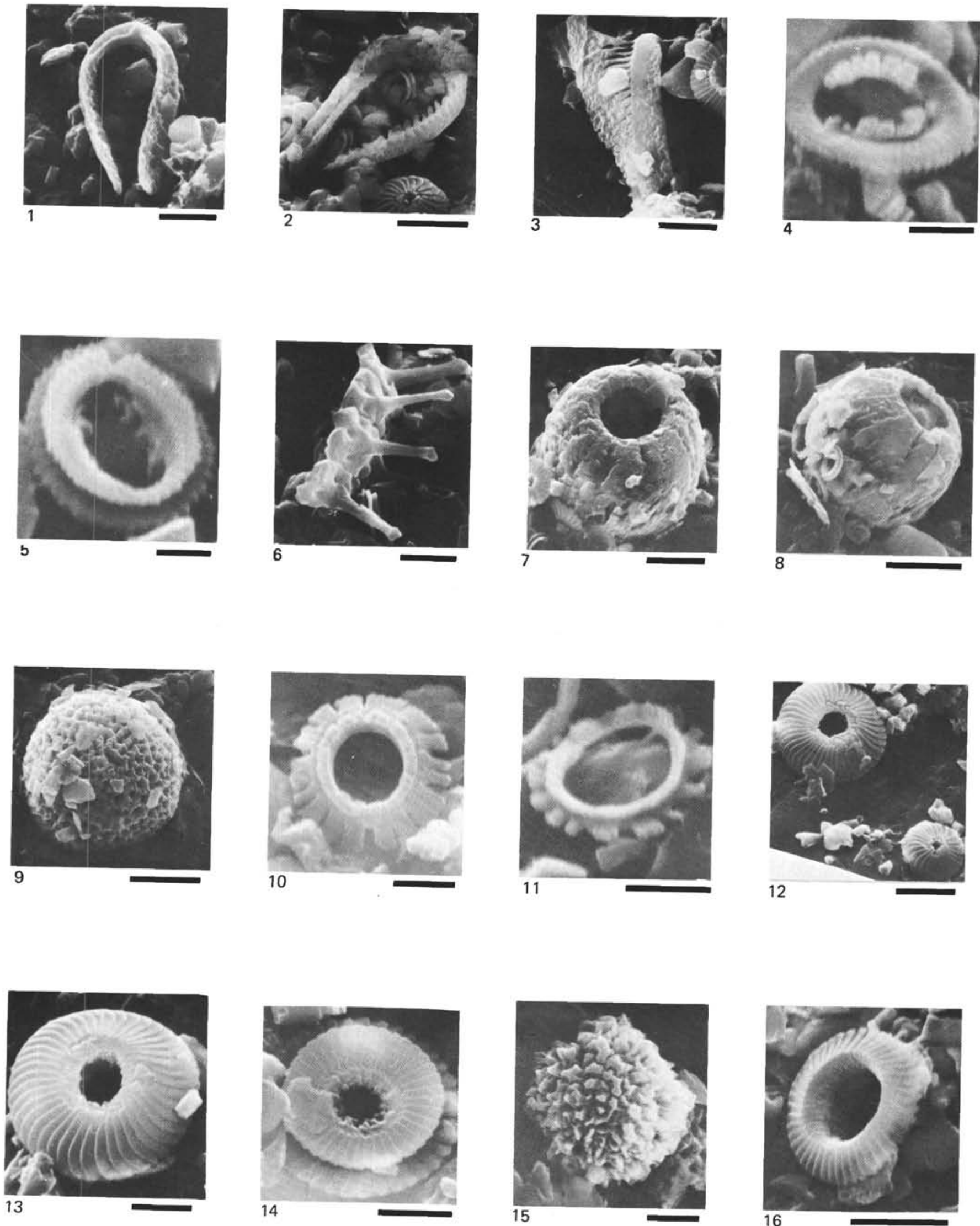
PLATE 5

Light Micrographs

Figures 1, 2 Parhabdolithus angustus, 3300×. Sample 417D-17-1, $13-15 \mathrm{~cm}$.

1. Crossed nicols.

2. interference contrast.

Figures 3, $4 \quad$ Parhabdolithus asper (lower right) and Lithraphidites carniolensis $1300 \times$. Sample 417D-21-4, 40-41 cm.

3. Crossed nicols.

4. Interference contrast.

Figure 5 Watznaueria barnesae, 2900×. Sample 417D-17-1, $13-15 \mathrm{~cm}$. Crossed nicols.

Figures 6,7 Lithraphidites carniolensis, 1600×. Sample 417D$17-1,13-15 \mathrm{~cm}$.

6. Crossed nicols.

7. Interference contrast.

Figures 8, 9 Markalius circumradiatus, 2700×. Sample 417D-31$3,130-131 \mathrm{~cm}$.

8. Crossed nicols.

9. Plane polarized light.

Figures 10, 11 Watznaueria communis, 2500×. Sample 417D-31-3, $130-131 \mathrm{~cm}$.

10. Crossed nicols.

11. Plane polarized light.

Figures 12, 13 Cretarhabdus conicus, 3000×. Sample 417D-21-4, $40-41 \mathrm{~cm}$.

12. Crossed nicols.

13. Interference contrast.

Figures 14, 15 Cretarhabdus crenulatus, 2200×. Sample 417D-17-1, $13-15 \mathrm{~cm}$.

14. Crossed nicols.

15. Plane polarized light.

Figures 16, 17 Prediscosphaera cretacea, 2800×. Sample 417D-17$1,13-15 \mathrm{~cm}$.

16. Crossed nicols.

17. Interference contrast.

Figures 18, 19 Zygodiscus diplogrammus, 4400×. Sample 417D-17$1,13-15 \mathrm{~cm}$.

18. Crossed nicols.

19. Interference contrast.

Figures 20, 21 Vagalapilla elliptica, 3200×. Sample 417D-21-4, 40-41 cm.

20. Crossed nicols.

21. Interference contrast. 
Plate 5

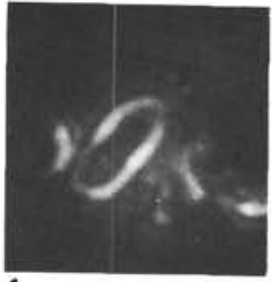

1
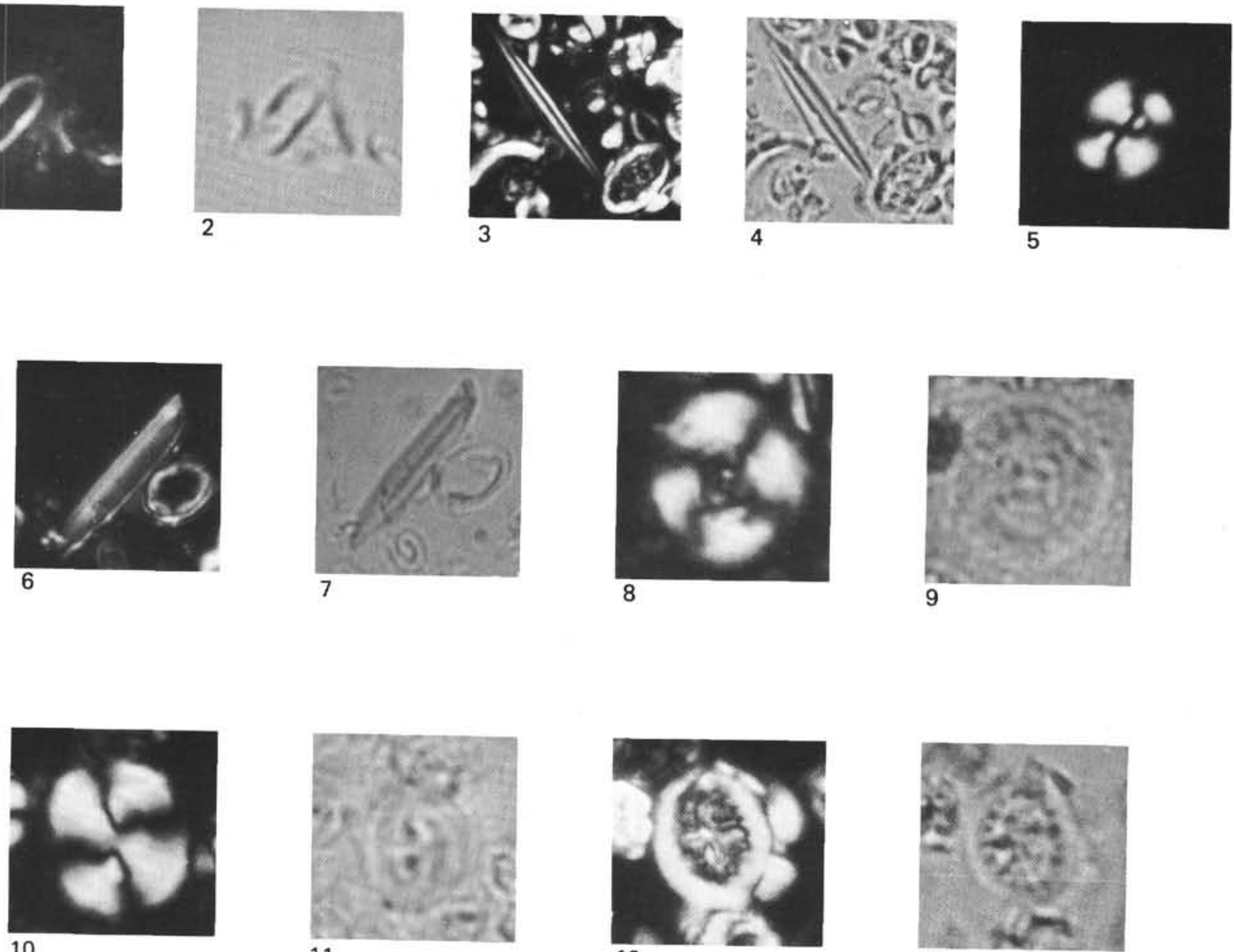

12

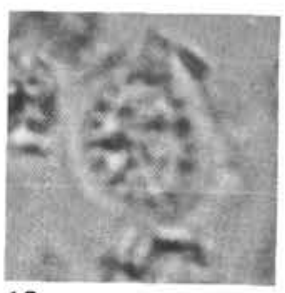

13
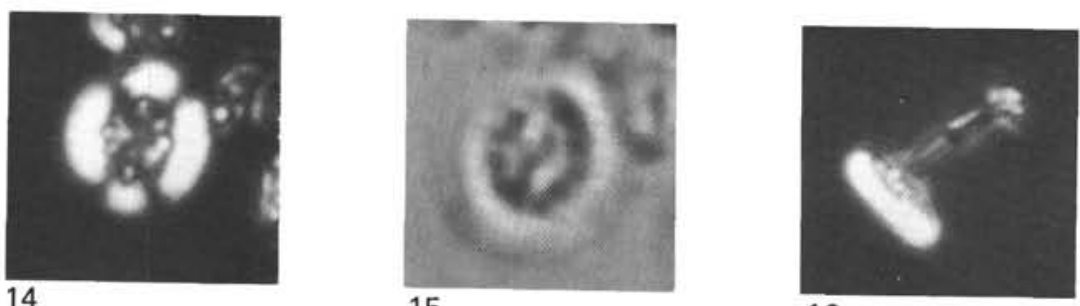

16

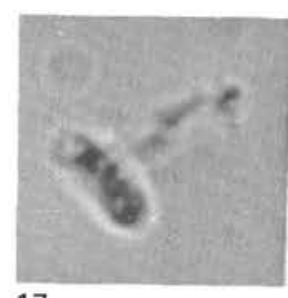

17
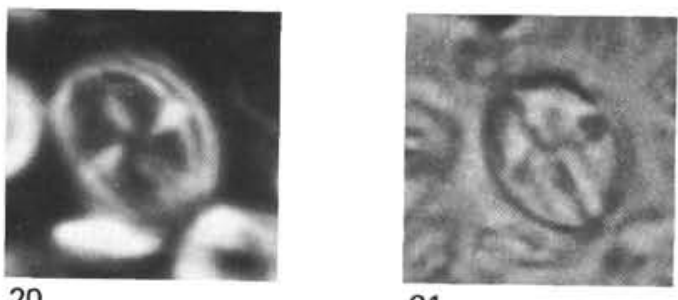

21 
PLATE 6

Light Micrographs

Figures 1, 2 Parhabdolithus embergeri, 2200×. Sample 417D$17-1,13-15 \mathrm{~cm}$.

1. Crossed nicols.

2. Interference contrast.

Figure 3 Parhabdolithus embergeri, 1550×. Sample 417D$17-1,13-15 \mathrm{~cm}$.

Figures 4, 5 Parhabdolithus embergeri, 2400×. Sample 417D21-4, 40-41 cm.

4. Crossed nicols.

5. Interference contrast.

Figures 6, 7 Reinhardites fenestratus, 3800×. Sample 417D-21-4, $40-41 \mathrm{~cm}$.

6. Crossed nicols.

7. Plane polarized light.

Figures 8, 9 Lithastrinus floralis, 1500×. Sample 417D-17-1, 13-15 cm.

8. Crossed nicols.

9. Interference contrast.

Figures 10, 11 Lithastrinus floralis, 3400×. Sample 417D-20-2, 30-31 cm.

10. Crossed nicols.

11. Interference contrast.

Figures 12, 13 Parhabdolithus infinitus, 1600×. Sample 417D-17-1, $13-15 \mathrm{~cm}$.

12. Crossed nicols.

13. Plane polarized light.

Figure 14 Nannoconus cf. N. kamptneri, 2000×. Sample 417D$31-3,130-131 \mathrm{~cm}$. Interference contrast.

Figure 15 Cretarhabdus loriei, 2300×. Sample 417D-17-1, $13-15 \mathrm{~cm}$. Crossed nicols.

Figures 16, 17 Chiastozygus litterarius, 1300×. Sample 417D-17-1, $13-15 \mathrm{~cm}$.

16. Crossed nicols.

17. Interference contrast.

Figures 18, 19 Micrantholithus obtusus, 1700×. Sample 417D-21-4, 40-41 cm.

18. Crossed nicols.

19. Interference contrast.

Figures 20, 21 Micrantholithus obtusus, 3200×. Sample 417D-21-4, $40-41 \mathrm{~cm}$.

20. Crossed nicols.

21. Interference contrast. 
PLATE 6
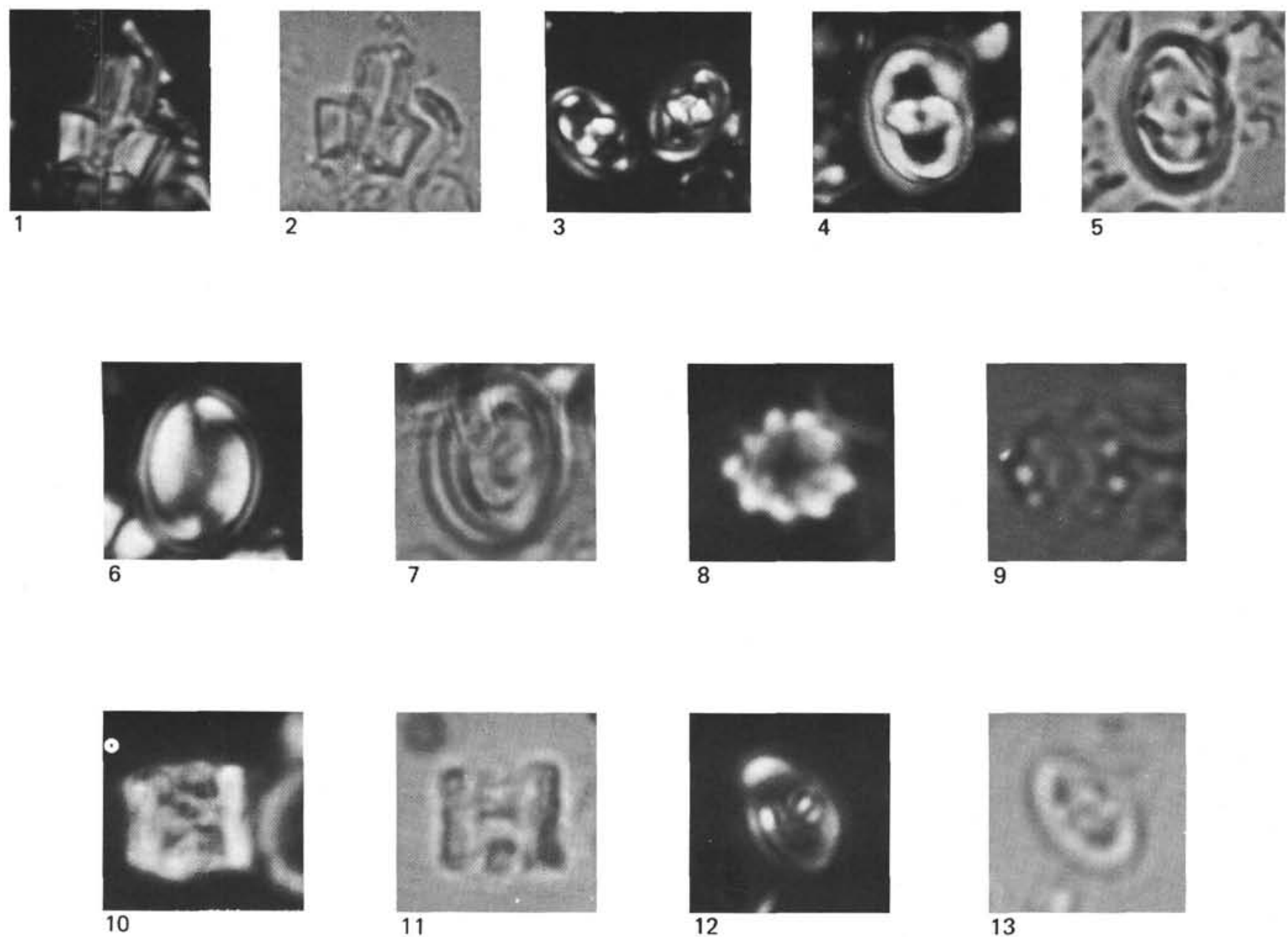

13
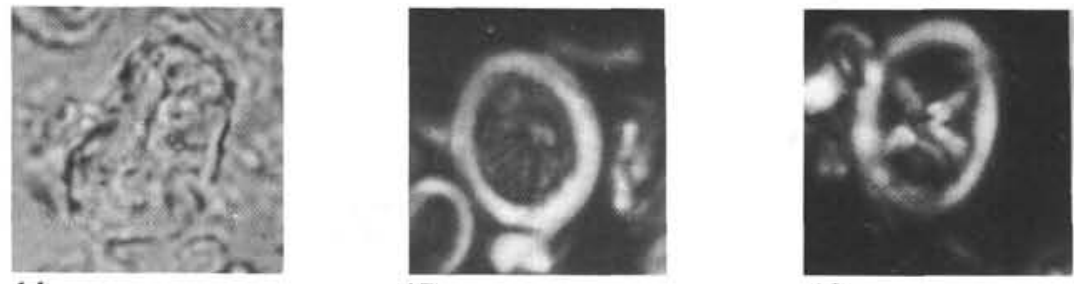

16

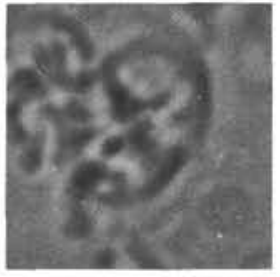

17
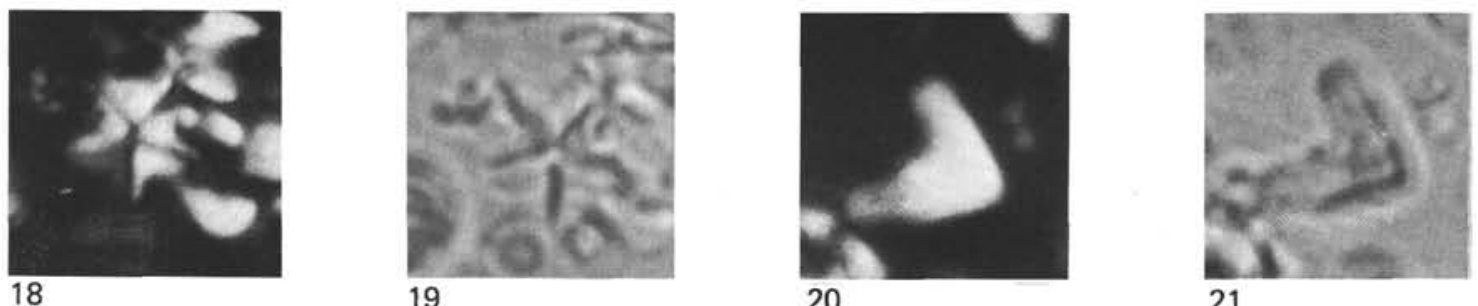

20 


\section{PLATE 7}

Light Micrographs

Figures 1, 2 Tranolithus orionatus, 3500×. Sample 417D-17-1, $13-15 \mathrm{~cm}$.

1. Crossed nicols.

2. Plane polarized light.

Figures 3, 4 Manivitella pemmatoidea, 2100×. Sample 417D-17$1,13-15 \mathrm{~cm}$.

3. Crossed nicols.

4. Interference contrast.

Figures 5, 6 Hayesites radiatus, 3200×. Sample 417D-31-3, 130$131 \mathrm{~cm}$.

5. Crossed nicols.

6. Plane polarized light.

Figures 7, 8 Hayesites sp., 3000×. Sample 417D-31-3, 130-131 $\mathrm{cm}$.

7. Crossed nicols.

8. Plane polarized light.

Figures 9, $10 \quad$ Rhabdolithus cf. $R$. rectus, 2000×. Sample 417D-21$4,40-41 \mathrm{~cm}$.

9. Crossed nicols.

10. Interference contrast.

Figures 11, 12 Nannoconus wassalli, 1900×. Sample 417D-21-3, $130-131 \mathrm{~cm}$.

11. Crossed nicols.

12. Interference contrast.

Figures 13, 14 Nannoconus sp., 2100×. Sample 417D-21-4, 40-41 $\mathrm{cm}$.

13. Crossed nicols.

14. Interference contrast,

Figures 15, 16 Nannoconus sp., 2700×. Sample 417D-31-3, 130-131 $\mathrm{cm}$.

15. Crossed nicols.

16. Interference contrast.

Figure 17 Eiffellithus turriseiffeli, 3300×. Sample 417D-17-1, $13-13 \mathrm{~cm}$. Crossed nicols.

Figures 18, 19 Tetralithus sp., 2700×. Sample 417D-21-3, 130-131 $\mathrm{cm}$.

18. Crossed nicols.

19. Interference contrast.

Figures 20, 21 Tetralithus sp.,3200×. Sample417D-21-4,40-41 cm. 20. Crossed nicols.

21. Plane polarized light. 
PLATE 7

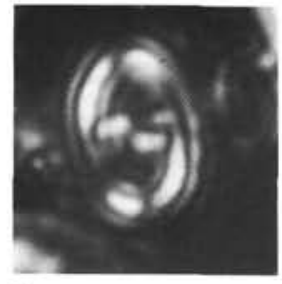

1

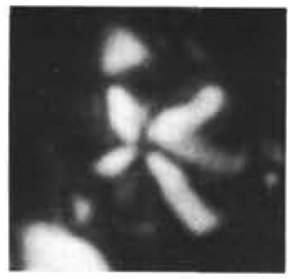

5
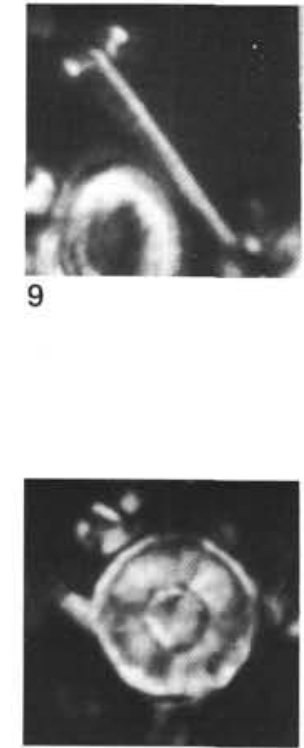

13

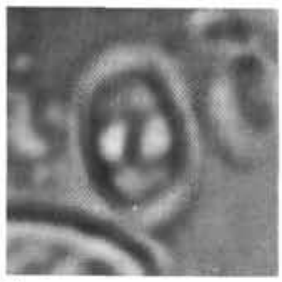

2
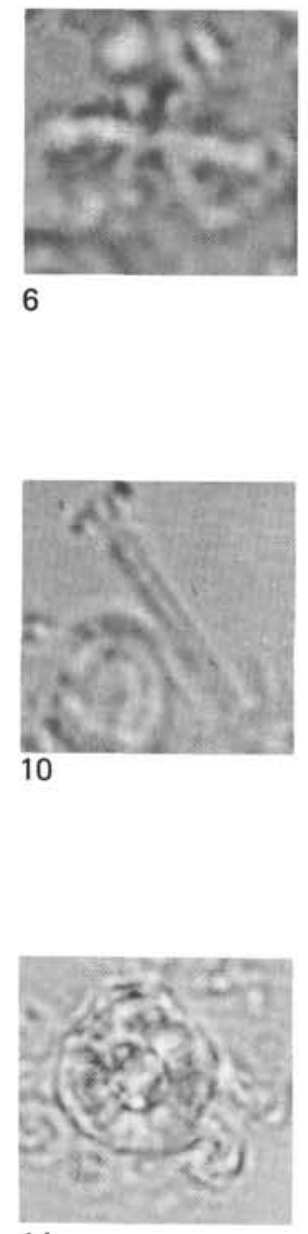

14
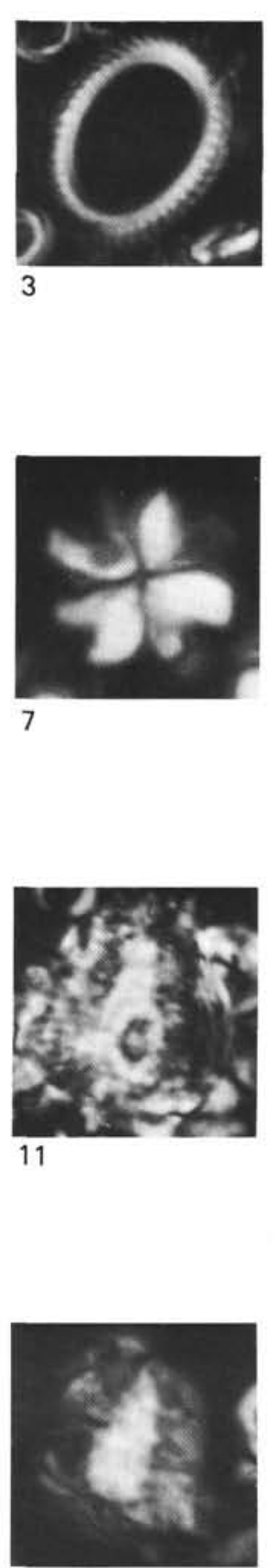

15
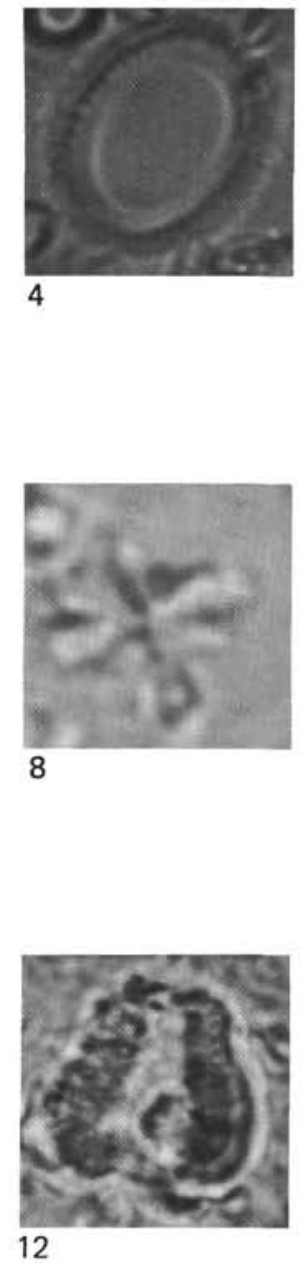

8

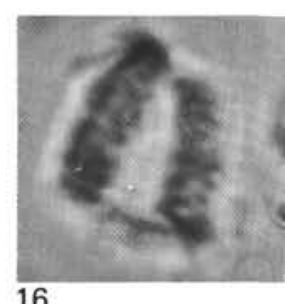

16

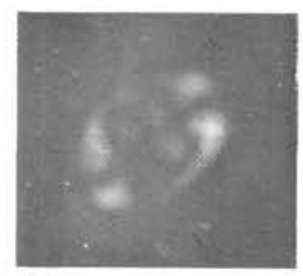

17

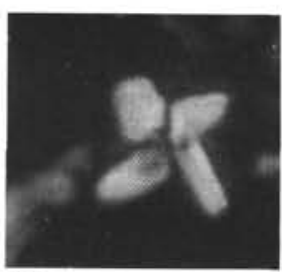

18

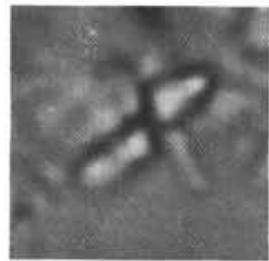

19

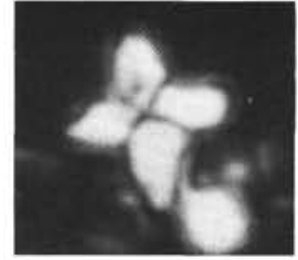

20

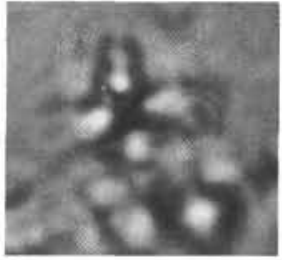

21 
PLATE 8

Light Micrographs

Figure $1 \quad$ Helicosphaera carteri, 3700×. Sample 418-1-4, 93-94 $\mathrm{cm}$. Crossed nicols.

Figure 2 Helicosphaera carteri, 2200×. Sample 418-1-4, 93-94 $\mathrm{cm}$. Crossed nicols.

Figures 3, 4 Ceratolithus cristatus, 1900×. Sample 418-1-4, 14-15 $\mathrm{cm}$.

3. Crossed nicols.

4. Interference contrast.

Figures 5, 6 Scyphosphaera globulosa, 1500×. Sample 418-1-4, 93-94 cm.

5. Crossed nicols.

6. Plane polarized light.

Figure 7 Gephyrocapsa sp., 5100×. Sample 417D-1-4, 14-15 $\mathrm{cm}$. Crossed nicols.

Figure $8 \quad$ Cyclococcolithus leptoporus, 4600×. Sample 417D1-4, 14-15 cm. Crossed nicols.

Figures 9, 10 Cyclococcolithus macintyrei, 2800×. Sample 418-1-4, $14-15 \mathrm{~cm}$.

9. Crossed nicols.

10. Interference contrast.

Figure 11 Cyclococcolithus macintyrei, 3200×. Sample 417D$1-4,14-15 \mathrm{~cm}$. Crossed nicols.

Figures 12, 13 Scyphosphaerapulcherrima, 2000×.Sample 418-1-4, 93-94 cm.

12. Crossed nicols.

13. Plane polarized light.

Figures 14, 15 Thoracosphaera cf.T. saxea, 1400×.Sample 418-1-4, 93-94 cm.

14. Crossed nicols.

15. Interference contrast.

Figures 16, 17 Thoracosphaera sp., 1400×. Sample 418-1-4, 93-94 $\mathrm{cm}$.

16. Crossed nicols.

17. Interference contrast.

Figures 18, 19 Ceratolithus telesmus, 1900×. Sample 418-1-4, 14-15 $\mathrm{cm}$.

18. Crossed nicols.

19. Interference contrast. 
PLATE 8
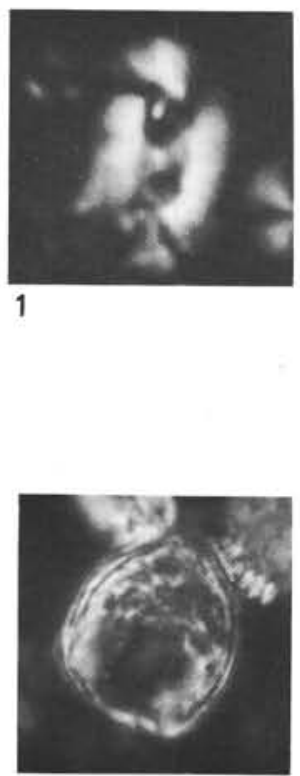

5

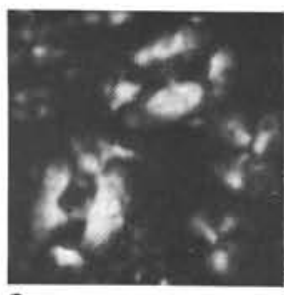

2

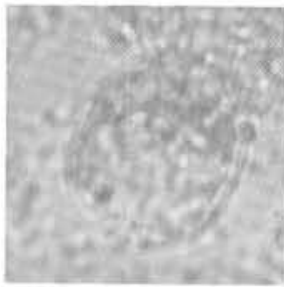

6

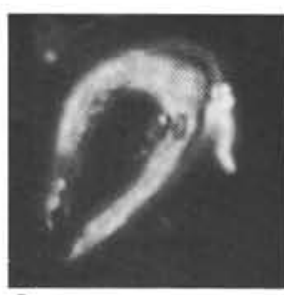

3

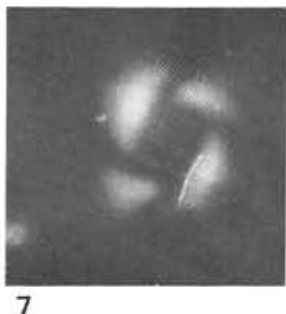

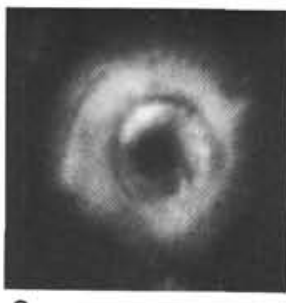

9

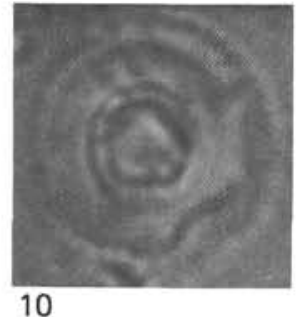

10

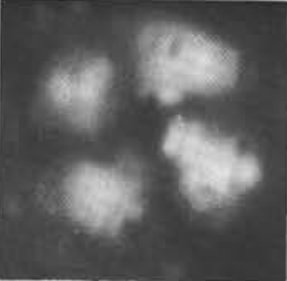

11
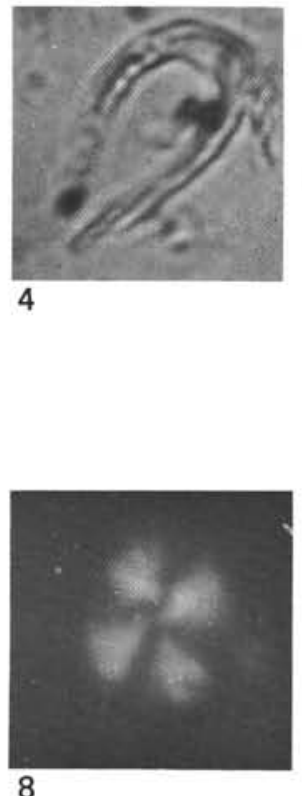

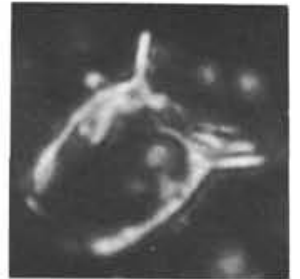

12

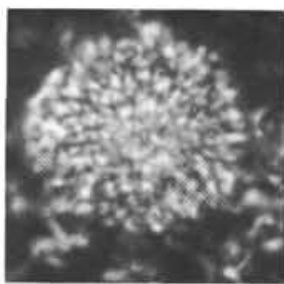

16

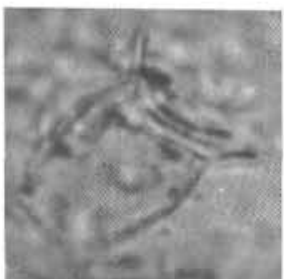

13
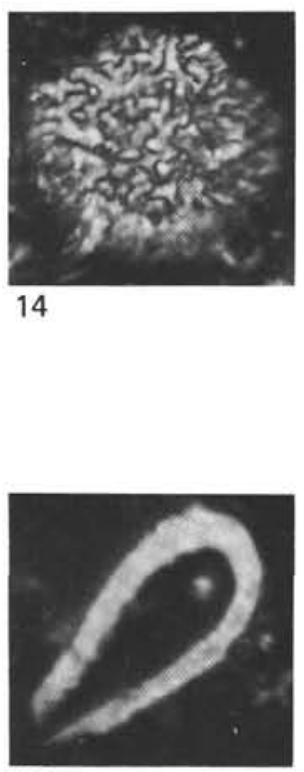

18

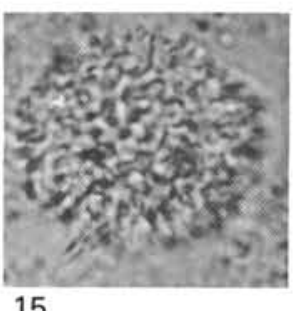

15

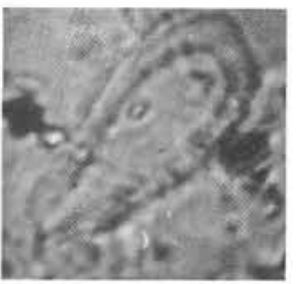

